\title{
The Public Interest Standard: Is It Too Indeterminate to Be Constitutional?
}

Randolph J. May

The Progress \& Freedom Foundation

Follow this and additional works at: https://www.repository.law.indiana.edu/fclj

Part of the Antitrust and Trade Regulation Commons, Communications Law Commons, Constitutional Law Commons, Consumer Protection Law Commons, and the Legislation Commons

\section{Recommended Citation}

May, Randolph J. (2001) "The Public Interest Standard: Is It Too Indeterminate to Be Constitutional?," Federal Communications Law Journal: Vol. 53 : Iss. 3 , Article 3.

Available at: https://www.repository.law.indiana.edu/fclj/vol53/iss3/3

This Article is brought to you for free and open access by the Law School Journals at Digital Repository @ Maurer Law. It has been accepted for inclusion in Federal Communications Law Journal by an authorized editor of Digital Repository @ Maurer Law. For more information, please contact rvaughan@indiana.edu.

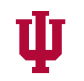

JEROME HALL LAW LIBRARY

INDIANA UNIVERSITY

Maurer School of Law
Bloomington 


\title{
The Public Interest Standard: Is It Too Indeterminate to Be Constitutional?
}

\author{
Randolph J. May*
}

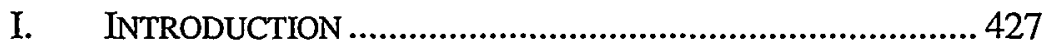

II. THE ORIGINS OF THE NONDELEGATION DOCTRINE AND ITS EARLY JUDICIAL IMPLEMENTATION

A. The Founders' Vision: Divided and

Separated Powers.

B. Early Nondelegation Jurisprudence ........................ 433

III. 1935: THE NONDELEGATION DOCTRINE COMES ALIVE ... 435

IV. AFTER PANAMA REFINING AND SCHECHTER POULTRY: NONDELEGATION DORMANCY AND REVIVAL.................. 438

V. THE PUBLIC INTEREST STANDARD: AN INDETERMINATE DELEGATION THAT CONSTITUTES AN ABDICATION OF CONGRESSIONAL RESPONSIBILITY

VI. CONCLUSION: A NEW DEREgulatory PARADIGM REQUIRES A NEW MEASURE OF CONGRESSIONAL ACCOUNTABLITY 452

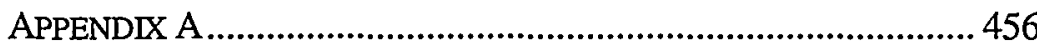

\section{INTRODUCTION}

More than three hundred years ago, in the second of his famous Two

* Randolph J. May is Senior Fellow and Director of Communications Policy Studies at The Progress \& Freedom Foundation, Washington, D.C. He received his A.B. and J.D. degrees from Duke University. This Article is reprinted with the permission of The Progress \& Freedom Foundation. A substantially similar version was originally published by the Foundation and released to the public at a conference sponsored by the Foundation on December 8,2000. The Author gratefully acknowledges the research assistance received from Ian Dillner in the preparation of this Article. 
Treatises, John Locke wrote that the legislature "cannot transfer the [p]ower of [m]aking [1]aws to any other hands. For it being but a delegated [p]ower from the [p]eople, they, who have it, cannot pass it over to others."1

In 1927, when Congress passed the initial legislation to oversee the nascent broadcasting industry, it delegated authority to the newly created regulatory agency, then called the Federal Radio Commission, to regulate broadcasters (and other users of the radio spectrum) in the "public interest." This standard has proven so indeterminate that, in adopting it, Congress passed off to the new agency the power to make law in a way that would surely shock Locke and the founders of our nation.

The Founders relied heavily on their understanding of Locke in devising a constitution based on separation of powers. They relied even more heavily on "the celebrated Montesquieu." In urging ratification of the proposed Constitution, Madison quoted extensively from Montesquieu in The Federalist No. 47, including Montesquieu's famous injunction that " $[w]$ hen the legislative and executive powers are united in the same person or body, ... there can be no liberty." ${ }^{4}$

Thus, when the Founders gathered in Philadelphia in the summer of 1787 to produce the Constitution, they wrote in Article I that "all legislative [p]owers herein granted shall be vested in a Congress of the United States." While Article I remains unchanged, a lot of water has passed under the constitutional bridge since 1787 regarding the separation of powers doctrine-so much so that perhaps, as a practical matter, no constitutional limits exist on Congress's ability to delegate its lawmaking authority to a federal agency.

This Article argues, however, that some limits do constrain Congress's ability to transfer lawmaking authority to another entity. Moreover, those nondelegation boundaries have been transgressed when Congress authorizes its delegatee-in this case the Federal Radio

1. John Locke, Two Treatises of Government 380 (Peter Laslett ed., Cambridge Univ. Press 2d ed. 1970) (1690) (emphasis omitted).

2. Radio Act of 1927, ch. 169, 44 Stat. 1162 (repealed 1934).

3. In The Federalist No. 47, Madison invokes "the celebrated Montesquieu" as the "oracle who is always consulted" on the subject of separation of powers. THE FEDERALIST No. 47, at 301 (James Madison) (Clinton Rossiter ed., 1961).

4. Id. at 303. For more discussion of the strong influence of Montesquieu's separation of powers theory on the Founders, see M.J.C. VILE, ConstitutionalisM AND THE SEPARATION OF POWERS 76-97 (1967).

5. U.S. CONST. art. I, $§ 1$. 
Commission's successor, the Federal Communications Commission ("FCC" or "Commission")— to simply act in the "public interest." In short, this Article will argue that the public interest standard, despite its longstanding history in the context of regulation of the communications industry, is inconsistent with the separation of powers principles vindicated in our constitutional system through the nondelegation doctrine.

The Communications Act of 1934 ("1934 Act") delegates authority to the FCC to regulate in the public interest with regard to both wireline and wireless communications. ${ }^{6}$ Indeed, Congress has directed or authorized the FCC to act in the public interest in nearly one hundred statutory provisions. ${ }^{7}$ Not surprisingly, much of the agency's most important regulatory activity takes place under the "public interest" rubric.

For example, in the name of the public interest, the FCC, at various times, has required or "encouraged" broadcasters to air particular types of programming, such as political broadcasts and editorials, news and weather reports, and children's programming. At the same time, it has prohibited or "discouraged" broadcasters from airing other types of programming, such as songs containing drug-oriented lyrics or too much sex. ${ }^{8}$ Recently, in the face of a fairly clear directive that it await further direction from Congress, the FCC relied on the public interest standard to mandate that broadcast networks and other multichannel video programming distributors provide a

6. The authority of the FCC to regulate radio (wireless) communications in the "public interest" or "public convenience, interest, or necessity" is found throughout Title III of the 1934 Act. See, e.g., 47 U.S.C. \$\$ 301-303, 307(a), 309(a), 310(d), 311(b)-(c)(3), 315(a), 319(c) (1994 \& Supp. IV 1998). In Title II of the 1934 Act, the FCC likewise possesses authority to regulate wireline communications in the "public interest," "public interest, convenience, and necessity," or "public convenience and necessity." Id. \$§ 214(a)-(d), 215(a) (1994); id. § 251(f)(2)(B), 271(d)(3)(C) (Supp. IV 1998). The "public interest" also represents a critical element of the standard for determining whether the Commission should forbear from regulation. See id. §§ 160(a)(3), 160(b) (Supp. IV 1998); id. § 201(b) (1994). The FCC interprets these similar phrases to mean in the "public interest," regardless of the variations in phraseology. For example, in the discussion in the FCC's Order approving the transfer of licenses as part of the SBC/Ameritech merger, the Commission determined the Title II and Title III standards, although worded slightly differently, to mean merely the "public interest." Applications of Ameritech Corp. and SBC Comm. Inc. for Consent to Transfer Licenses and Lines, Memorandum Opinion and Order, 14 F.C.C.R. 14,712, paras. 46-54, 18 Comm. Reg. (P \& F) 1 (1999) [hereinafter Ameritech Corp. \& SBC Comm. Inc.]. To the same effect, see Glen O. Robinson, The Federal Communications Act: An Essay on Origins and Regulatory Purpose, in A LEGISLATIVE HISTORY OF THE COMMUNICATIONS ACT OF 1934 3, 15-16 (Max D. Paglin ed., 1989).

7. For the list of statutory provisions, see infra Appendix A.

8. Thomas G. Krattenmaker \& Lucas A. Powe, JR., Regulating Broadcast PROGRAMMING 104-19 (1994). 
minimum number of hours of programming with narrated video descriptions. ${ }^{9}$

The FCC has employed its public interest authority to promulgate multiple- and cross-ownership rules, which determine or affect the structure and organization of the broadcasting, newspaper, cable, cellular, and other communications sectors. ${ }^{10}$ Similarly relying upon the public interest standard, in the context of reviewing transfers of controls of licenses and other forms of authorization, the FCC has imposed conditions on mergers that go far beyond the existing requirements of the statute or its own rules. ${ }^{11}$ With the FCC making such far-reaching decisions concerning the permissible and prohibited activities of communications industry participants, and the structure and organization of the industry in the name of the public interest, it is worth asking anew whether such an indeterminate and vague delegation passes constitutional muster. ${ }^{12}$

This Article does not examine the related, but broader question of the constitutional status of so-called independent regulatory agencies such as the FCC. ${ }^{13}$ Most of these agencies sprouted up during the first half of the

9. Implementation of Video Description of Video Programming, Report and Order, 15 F.C.C.R. 15,230 para. 6, 21 Comm. Reg. (P \& F) 904 (2000).

10. See, e.g., FCC v. Nat'l Citizens Comm. for Broad., 436 U.S. 775 (1978); NBC, Inc v. United States, 319 U.S. 190 (1943).

11. See, e.g., Ameritech Corp. \& SBC Comm. Inc., supra note 6; Application of WorldCom, Inc. and MCI Comm. Corp. for Transfer of Control, Memorandum Opinion and Order, 13 F.C.C.R. 18,025, 13 Comm. Reg. (P \& F) 477 (1998); Applications of NYNEX Corp. and Bell Atl. Corp. for Consent to Transfer Control, Memorandum Opinion and Order, 12 F.C.C.R. 19,985, 9 Comm. Reg. (P \& F) 187 (1997).

12. This Article says "anew," because early in the history of the regulation of radio broadcasting, the Supreme Court rejected arguments that the public interest standard was unconstitutionally vague. NBC, Inc., 319 U.S. at 216; Fed. Radio Comm'n v. Nelson Bros. Bond \& Mortgage Co., 289 U.S. 266, 285 (1933).

13. To an even greater extent than the executive branch agencies, independent regulatory agencies, such as the FCC, FTC, SEC, and the Commodities Futures Trading Commission, seem to constitute a "headless fourth branch" of government, in that, after Humphrey's Executor v. United States, 295 U.S. 602 (1935), they are thought to exist free from direct presidential control. While the Supreme Court's dicta in Humphrey's Executor seems to validate the constitutional status of the independent agencies despite separation-ofpowers concerns, see id. at 631-32, the Court has never directly ruled on the issue. From time to time, lower courts have intimated that the question of the constitutionality of the independent agencies "raise[s] a serious and substantial issue." See Ticor Title Ins. Co. v. FTC, 625 F. Supp. 747, 751 (D.D.C. 1987). Commentators have continued to debate the issue as well, often suggesting that the Court "should hold that the President [indeed] can control policymaking by [the] independent agencies." Richard J. Pierce, Political Accountability and Delegated Power: A Response to Lowi, 36 AM. U. L. REv. 391, 411-12 (1987); see also Harold H. Bruff, On the Constitutional Status of Administrative Agencies, 
twentieth century, when it was fashionable to assume that whole industry sectors should be regulated by bipartisan commissions staffed by government "experts." The fact that questions persist concerning the constitutionality of these independent commissions in our tripartite scheme of government should counsel against tolerating overly broad delegations that further exacerbate separation of powers concerns.

This Article will examine, first, the historical origins of the nondelegation doctrine and its early jurisprudence (up to the New Deal) in order to understand the doctrine's rationale and purpose. Then, this Article will examine the two landmark cases of 1935, Schechter Poultry Corp. v. United States, ${ }^{14}$ and Panama Refining Co. v. Ryan, ${ }^{15}$ which marked the last cases in which the Supreme Court held sections of a statute unconstitutional on nondelegation grounds. Next, this Article will examine developments post-1935, including in more recent years what seems to be a revival of interest in the nondelegation doctrine, particularly among commentators, but now, also possibly in the courts.

Finally, this Article will show that, regardless of whether the apparent revival of interest in the doctrine casts doubt on the constitutionality of a broader swath of indeterminate statutes, it is time for Congress (or the Court, if Congress fails to act) to revisit delegation under the public interest standard. In light of the relative newness of the radio and telephone industries when the 1934 Act passed-and the much more monopolistic environment in which these nascent industries operated-Congress's inclination to delegate such unfettered discretion to the new "expert" agency was perhaps understandable.

Today, however, in an environment of "convergence" in which competition is flourishing across communications sectors, Congress should not shirk its responsibility to establish fundamental policy for an important industry that contributes so much to the overall health of our economy. Congress should not wait for the courts possibly to require the replacement

36 AM. U. L. REv. 491, 512-14 (1987). Both of these articles appear in a special issue of the AMERICAN UNIVERSITY LAW REVIEW entitled A Symposium on Administrative Law: The Uneasy Constitutional Status of Administrative Agencies, 36 AM. U. L. REV. 277 (1987), which contains many other pieces addressing this same subject. This Article does not argue that the FCC, as a so-called independent regulatory agency, is unconstitutional in and of itself as a breach of the separation of powers doctrine. The fact that such status is subject to question, however, should suggest the need for additional caution in considering whether the Constitution permits overly broad delegations of authority.

14. 295 U.S. 495 (1935).

15. 293 U.S. 388 (1935). 
of the public interest standard with more specific congressional guidance to the agency-guidance that hopefully will provide an unmistakable roadmap toward a deregulatory end game consistent with a competitive marketplace.

\section{THE ORIGINS OF THE NONDELEGATION DOCTRINE AND ITS EARLY JUDICIAL IMPLEMENTATION}

\section{A. The Founders' Vision: Divided and Separated Powers}

In devising the Constitution's structure, the Founders relied heavily on Montesquieu's arguments. In his famous work, The Spirit of Laws, Montesquieu assumed that men likely will abuse power if no constraints exist on their ability to exercise it. Thus, long before Lord Acton uttered his famous dictum, ${ }^{16}$ Montesquieu admonished that "constant experience $\operatorname{sh}[\mathrm{o}]$ ws us[] that every man invested with power is apt to abuse it, and to carry his authority as far as it will go."17 To protect liberty by checking this human tendency towards power aggrandizement, Montesquieu advocated what he referred to as a "constitution of liberty" based on a division of governmental powers:

When the legislative and executive powers are united in the same person, or in the same body of magistrates, there can be no liberty; because apprehensions may arise, lest the same monarch or senate should enact tyrannical laws, to execute them in a tyrannical manner.

Again, there is no liberty, if the judiciary power be not separated from the legislative and executive.

There would be an end of every thing, were the same man, or the same body, whether of the nobles or of the people, to exercise those three powers, that of enacting laws, that of executing the public resolutions, and of trying the causes of individuals. ${ }^{18}$

Thus, in Montesquieu's view, the structure of a constitution-the way in which the charter divides and assigns authority-is key to the ultimate protection of liberty.

When the Founders drafted the Constitution, they adopted Montesquieu's model-a model more refined than the earlier Lockean

16. "Power tends to corrupt, and absolute power corrupts absolutely." Letter from John Emerich Edward Dalberg-Acton to Bishop Mandell Creighton (Apr. 5, 1887), reprinted in Lord Acton, ESSAYS ON FREEDOM AND POWER 355 (Gertrude Himmelfarb ed., 1972).

17. 1 MoNTESQUIEU, The SPIRIT OF LAws 172 (Thomas Nugent trans., Robert Clarke \& Co. 1873).

18. Id. at 174. 
version, which tended to minimize the significance of the judiciary. Article I provides that "[a]11 legislative [p]owers herein granted shall be vested" in Congress. ${ }^{19}$ Articles III and III provide that the executive and judicial powers shall be vested respectively in a President and the federal courts. ${ }^{20}$

In defending the proposed Constitution against the contention that it allowed too much blending of the separate departments' powers, Madison stated:

No political truth is certainly of greater intrinsic value, or is stamped with the authority of more enlightened patrons of liberty than that on which the objection is founded. The accumulation of all powers, legislative, executive, and judiciary, in the same hands ... may justly be pronounced the very definition of tyranny. Were the federal Constitution, therefore, really chargeable with this accumulation of power, or with a mixture of powers, having a dangerous tendency to such accumulation, no further arguments would be necessary to inspire a universal reprobation of the system. ${ }^{21}$

Like Montesquieu, Madison based his concern for a division of authority on the conviction-widely shared by the Founders-that "power is of an encroaching nature and .... it ought to be effectually restrained from passing the limits assigned to it. ${ }^{, 22}$

\section{B. Early Nondelegation Jurisprudence}

A brief review of the pre-New Deal cases shows how the application of the nondelegation doctrine evolved from its early, more formalistic separation-of-powers roots to a more functional approach at the time of the New Deal. In 1825, in Wayman v. Southard, the Supreme Court sustained a statute that permitted the Court to promulgate rules governing the service of process and execution of judgments in the federal courts. ${ }^{23}$ While avoiding what he described as the "delicate and difficult" task of defining the precise boundary of "legislative power," indicated that whether the subject of the purported delegation was "important" or of "less interest" would bear on its constitutionality. If

19. U.S. Const. art. I, $\S 1$.

20. Id. art. II, § 1; id. art. III, §1.

21. ThE FEDERALIST No. 47 , supra note 3.

22. ThE Federalist No. 48, at 308 (James Madison) (Clinton Rossiter ed., 1961).

23. 23 U.S. (10 Wheat.) 1.

24. Id. at 46 .

25. Id. at 47 .

26. Id. at 43 . 
important, then it "must be entirely regulated by the legislature itself," but if of less interest, then the delegatee might "fill up the details." 27

In 1892, in Field v. Clark, the Supreme Court said rather straightforwardly: "That Congress cannot delegate legislative power to the President is a principle universally recognized as vital to the integrity and maintenance of the system of government ordained by the Constitution. ${ }^{28}$ The Court sustained a tariff statute that required the President to suspend favorable tariff treatment for any country that he determined imposed on American products any "exactions and duties ... which he found to be[] reciprocally unequal and unreasonable." 29 The Court upheld the statute on the basis that Congress itself had specified the goods, fixed the tariff levels, and set the standard that would trigger retaliatory action. ${ }^{30}$ The President needed only to "ascertain[] the existence of a particular fact"-inequality in the duties, which Congress had declared would trigger the suspension." Thus, in this view, the President did not function as a lawmaker; rather "[h]e was the mere agent of the law-making department to ascertain and declare the event upon which its expressed will was to take effect." ${ }^{32}$

The early nondelegation cases, like Field v. Clark, adopted a formalistic approach in that they framed the issue as whether the delegated authority was, in fact, "legislative." If legislative, such delegation was unconstitutional; if not, it was constitutional. By 1928, however, there was a shift, even if only a somewhat subtle one, in the analytical framework.

In J. W. Hampton, Jr. v. United States, another case challenging the President's administration of a tariff established by Congress, the Court used language implying a somewhat new nondelegation standard, one that, in theory, survives to this day. ${ }^{33}$ The tariff statute at issue in J. W. Hampton authorized the President to adjust the congressionally established schedule by any amount necessary to "equalize the ... costs of production in the United States and the principal competing country." ${ }^{34}$ Rejecting a nondelegation contention, the Court stated: "If Congress shall lay down by legislative act an intelligible principle to which the person or body
27. Id.
28. 143 U.S. $649,692$.
29. Id. at 692 .
30. Id.
31. Id. at 693.
32. Id.
33. 276 U.S. 394 (1928).
34. Id. at 401. 
authorized to fix such rates is directed to conform, such legislative action is not a forbidden delegation of legislative power., ${ }^{35}$ So while the earlier, more formalistic nondelegation cases generally used language implying that no legislative power could be delegated, the announcement of the "intelligible principle" test refined the inquiry, including the determination whether Congress had sufficiently set forth policy guidelines for the delegatee to follow. ${ }^{36}$

\section{1935: THE NONDELEGATION DOCTRINE COMES ALIVE}

Applying the test laid down in $J$. W. Hampton in 1935, the Supreme Court found delegations to be unconstitutional in two New Deal cases, both involving the National Industry Recovery Act ("NIRA"). In Panama Refining Co. v. Ryan, the Court held unlawful a section of the NIRA that authorized the President to prohibit the shipment in interstate commerce of so-called "hot oil," that is, petroleum products produced in excess of amounts allowed under state law. ${ }^{38}$ In some respects, as Justice Cardozo argued in a lonely dissent, the delegation seemed akin to those earlier tariff cases in which the Court upheld challenged delegations on the basis that the executive's action occurred only in a specified contingency. ${ }^{39}$

With Chief Justice Hughes writing for the Court, however, the majority held that section 9(c) of NIRA violated the nondelegation doctrine because it "[did] not state whether, or in what circumstances or under what conditions, the President is to prohibit the transportation of the amount of petroleum or petroleum products produced in excess of the State's permission. It establishe[d] no criterion to govern the President's course." The Court said that if the challenged delegation were allowed to stand,

35. Id. at 409. Note that in J. W. Hampton, the statute allowed the President actually to adjust the tariff rate, whereas in Field, the President determined whether the particular preordained congressional remedy should apply.

36. While the sources and cases discussed in this section are well-known and the subject of countless commentaries, the rendition here owes much to Professor Farina's lucid recounting in Cynthia R. Farina, Statutory Interpretation and the Balance of Power in the Administrative State, 89 CoLUM. L. REv. 452, 479-88 (1989). In the context of a larger work concerning the appropriate roles of the courts and administrative agencies in our constitutional system, Professor Farina's article is an excellent source for an overall grounding in the separation-of-powers concerns at the heart of the nondelegation issue.

37. Panama Ref. Co. v. Ryan, 293 U.S. 388, 430 (1935); A.L.A. Schechter Poultry Corp. v. United States, 295 U.S. 495, 537 (1935).

38. 293 U.S. at $415-18$.

39. Id. at 442-44 (Cardozo, J., dissenting).

40. Id. at 415 . 
"[i]nstead of performing its law-making function, the Congress could at will and as to such subjects as it chose transfer that function to the President or other officer or to an administrative body. ${ }^{, 41}$ Viewed in this light, the question turns on the importance not of the statute at issue, "but of the constitutional processes of legislation which are an essential part of our system of government." 42

A few months after the Panama Refining decision, the Supreme Court decided Schechter Poultry, often referred to as the "sick chicken" case. There, the Court invalidated the "Live Poultry Code" adopted under another NIRA provision authorizing the President to promulgate "codes of fair competition" for various trade sectors. ${ }^{43}$ Under the statute, the President, in considering code proposals submitted to him by private trade or industrial groups or those prepared on his own motion, could virtually impose any condition or requirement on industry "in his discretion." Typically, in formulating the competition codes, the President fixed the number of hours in the work week, minimum wages, minimum age for workers, and various trade practices, ${ }^{45}$ such as, in the case of the poultry code, acceptable chicken-killing methods. ${ }^{46}$

In the throes of the Depression, the Court acknowledged NIRA's claimed beneficent purpose to address the nation's economic woes. ${ }^{47}$ Nevertheless, Chief Justice Hughes writing for a now unanimous Court concluded that "Congress cannot delegate legislative power to the President to exercise an unfettered discretion to make whatever laws he thinks may be needed or advisable for the rehabilitation and expansion of trade or industry. ${ }^{, 48}$ The Court recognized the need for Congress to adapt legislation "to complex conditions involving a host of details with which the national legislature cannot deal directly," "but, "if our constitutional system is to be maintained, ${ }^{, 50}$ Congress itself must not be permitted "to transfer to others

41. Id. at 430 .

42. Id.

43. Schechter Poultry, 295 U.S. at 536-37.

44. National Industrial Recovery Act, ch. 90, 48 Stat. 195, 196 (1933) (codified as amended at 15 U.S.C. $\$ 703(1994)$ ).

45. 295 U.S. at 524.

46. Id. at 527 .

47. Id. at 550 .

48. Id. at 537-38.

49. Id. at 530 .

50. Id. 
the essential legislative functions with which it is thus vested." ${ }^{51}$

The Court acknowledged that the statute required the President to find that the code was "not 'designed to promote monopolies or to eliminate or oppress small enterprises and will not operate to discriminate against them." " 52 The Court said, however, that "these restrictions leave virtually untouched the field of policy envisaged by [the statute], and, in that wide field of legislative possibilities, the proponents of a code, refraining from monopolistic designs, may roam at will and the President may approve or disapprove their proposals as he may see fit., ${ }^{\text {,53 }}$

This time, Justice Cardozo did not dissent. In a famous concurrence, he was not unsympathetic to the congressional aims and the difficulty the legislature faced "in respect of matters such as these, to legislate directly with adequate appreciation of varying conditions. ${ }^{, 54}$ He found, however, that the statutory authorization would allow the President to do anything that Congress could do within the limits of the Commerce Clause. ${ }^{55}$ According to Cardozo, "[t]his is delegation running riot.,"56

As noted in the following section of this Article, not since 1935 has the Supreme Court held a statute unconstitutional under the nondelegation doctrine. ${ }^{57}$ Perhaps more importantly, though, the Court has never formally

51. Id. at 529 .

52. Id. at 538 (internal quotation omitted in original).

53. Id. In striking down the NIRA provision, the Court distinguished cases involving broad delegations to administrative agencies that it had upheld, including the public interest standard in Federal Radio Commission v. Nelson Brothers Bond and Mortgage Co., 289 U.S. 266 (1933). The Schechter Court stated that the public interest standard "was limited by the nature of radio communications, and by the scope, character and quality of the services to be rendered and the relative advantages to be derived through distribution of facilities." Schechter Poultry, 295 U.S. at 540. The Court also referred to the fact that an administrative body should administer the standard after a hearing and the submission of evidence. Id. This Article argues that these distinctions lack constitutional significance. If anything, the nature of the "independent" regulatory commissions, such as the FCC, FTC, and now-defunct ICC to which the Court also referred, raise independent separation-ofpowers concerns because of their hybrid nature, which are only exacerbated by overly broad delegations. See discussion supra note 13.

54. Schechter Poultry, 295 U.S. at 552 (Cardozo, J., concurring).

55. Id. at 553.

56. Id.

57. In Carter v. Carter Coal Co., 298 U.S. 238, 316-17 (1936), the Court invalidated NIRA-like legislation establishing a Bituminous Coal Code, which authorized coal producers and miners to set minimum wages and prices. The Court invalidated the statutory provision on substantive due process grounds, but the citation to Schechter Poultry indicates that today the Court would likely decide the case on nondelegation grounds. Id. at 311-12. 
abandoned the doctrine. In recent years, moreover, there has been renewed interest among commentators, and now, perhaps by the courts, in resuscitating the doctrine.

\section{AFTER PANAMA REFINING AND SCHECHTER POULTRY: NONDELEGATION DORMANCY AND REVIVAL}

With the quick rise of the regulatory state after Panama Refining and Schechter Poultry, the nondelegation doctrine, at least in its hard or pure form, fell somewhat out of fashion, but not completely out of use. Although the Supreme Court has not explicitly invalidated a statute on nondelegation grounds since 1935, on rare occasions, lower federal courts have. For example, in 1995, the Eighth Circuit Court of Appeals held unconstitutional on nondelegation grounds a section of the Indian Gaming Regulatory Act, which authorized the Secretary of the Interior to acquire any interest in lands within or outside a reservation for the "purpose of 'providing land for the Indians." ${ }^{\prime 58}$ The court held that the statute provided no intelligible principles or boundaries by which the public use underlying a particular acquisition could be defined.

While the Supreme Court and lower courts have been reluctant to hold statutes unconstitutional on explicit nondelegation grounds, they have not been as reluctant to employ a "soft" form of the doctrine. As Cass Sunstein, one of the leading academics in the public law field, recently put it:

It is often said that the nondelegation doctrine is dead.

On the contrary, I believe that the doctrine is alive and well. It has been relocated rather than abandoned. Federal courts commonly vindicate not a general nondelegation doctrine, but a series of more specific and smaller, though quite important, nondelegation doctrines. Rather than invalidating federal legislation as excessively open-ended, courts hold that federal administrative agencies may not engage in certain activities unless and until Congress has expressly authorized them to do so. The relevant choices must be made legislatively rather than bureaucratically. As a technical matter, the key holdings are based not on the nondelegation doctrine but on certain "canons" of construction. ${ }^{60}$

58. South Dakota v. Dep't of Interior, 69 F.3d 878, 885 (8th Cir. 1995), vacated and remanded, 519 U.S. 919, 920-23 (1996) (Scalia, J., dissenting on grounds that change in Petitioner's position formed unreasonable basis to vacate and remand).

59. Id. at 882 .

60. Cass R. Sunstein, Nondelegation Canons, 67 U. CHI. L. REv. 315, 315-16 (2000). 
This "relocated" doctrine has even been referred to as the "new delegation doctrine.",

Industrial Union Department v. American Petroleum Institute ${ }^{62}$ probably represents the most well-known case in which the Supreme Court employed a version of the reformulated nondelegation doctrine. This decision, often referred to as the "Benzene" case, involved review of an Occupational Safety and Health Administration ("OSHA") rule that would have imposed stringent measures to reduce worker exposure to benzene, a carcinogen. ${ }^{63}$ The Occupational Safety and Health Act required the agency to set standards for exposure to toxic materials which would protect workers "to the extent feasible." which reduced substantially the exposure limit without finding that exposure above the revised limit created a significant health risk. ${ }^{65}$

In a plurality opinion, four Justices rejected a nondelegation doctrine challenge, because they read into the statute's "feasibility" standard the requirement that the agency consider whether absence of the rule created a significant health risk. ${ }^{66}$ Justice Stevens reasoned:

If the Government were correct in arguing [that the statute does not require] that the risk from a toxic substance be quantified sufficiently to enable the Secretary to characterize it as significant in an understandable way, the statute would make such a "sweeping delegation of legislative power" that it might be unconstitutional under the Court's reasoning in [Schechter and Panama Refining]. A construction of the statute that avoids this kind of open-ended grant

According to Sunstein, examples would be the canons that dictate that "[a]dministrative agencies are not permitted to construe federal statutes in such a way as to raise serious constitutional questions" or that "Congress must affirmatively authorize the extraterritorial application of federal law." Id. at 316.

61. Lisa Schultz Bressman, Schechter Poultry at the Millennium: A Delegation Doctrine for the Administrative State, 109 YALE L.J. 1399, 1415 (2000).

The newly emerging delegation doctrine requires administrative agencies to issue rules containing reasonable limits on their discretion in exchange for broad grants of regulatory authority. Thus, the new delegation doctrine upholds the congressional transfer of lawmaking authority to administrative agencies, but imposes restraints on the exercise of that authority. Instead of demanding intelligible principles from Congress, it permits agencies to select their own Id. standards, consistent with the broad purposes of the statutory scheme.

62. 448 U.S. 607 (1980).

63. Id. at 611 .

64. Id. at 612 .

65. Id. at 615,623 .

66. Id. at 642-46. 
should certainly be favored. ${ }^{67}$

Thus, the Court avoided holding that the statute violated the nondelegation doctrine by construing the statute to include a limiting risk assessment principle.

Then-Justice Rehnquist, who provided the fifth vote to invalidate the agency's benzene rule, would have held the relevant provision of the OSHA statute-with its legislative direction to regulate "to the extent feasible"-unconstitutional as a standardless delegation. ${ }^{68}$ Justice Rehnquist thought the statutory provision, with its "completely precatory" phraseology, gave the agency "absolutely no indication where on the continuum of relative safety [it] should draw [the] line."

Justice Rehnquist used the occasion of his "Benzene" concurrence to succinctly sum up the functions of the nondelegation doctrine:

First ... it ensures to the extent consistent with orderly governmental administration that important choices of social policy are made by Congress, the branch of our Government most responsive to the popular will .... Second, the doctrine guarantees that, to the extent Congress finds it necessary to delegate authority, it provides the recipient of that authority with an "intelligible principle" to guide the exercise of the delegated discretion. Third, ... the doctrine ensures that courts charged with reviewing the exercise of delegated legislative discretion will be able to test that exercise against ascertainable standards. $^{70}$

Observing, even then, a revival of interest in reinvigorating the nondelegation doctrine, ${ }^{71}$ Justice Rehnquist urged his colleagues "to reshoulder the burden of ensuring that Congress itself make[s] the critical policy decisions. ${ }^{72} \mathrm{He}$ conceded that in the contemporary political environment, Congress runs into opposition when making policy decisions, no matter how it formulates legislation:

But that is the very essence of legislative authority under our system. It is the hard choices, and not the filling in of the blanks, which must be made by the elected representatives of the people. When fundamental policy decisions underlying important legislation about to be enacted are to be made, the buck stops with Congress and the President insofar

67. Id. at 646 .

68. Id. at 687-88.

69. Id. at 675 .

70. Id. at 685-86 (citations omitted) (emphasis added).

71. See id. at $687 \mathrm{n} .6$.

72. Id. at 687. 
as he exercises his constitutional role in the legislative process. ${ }^{73}$

In other words, according to Justice Rehnquist, the fact that Congress faces difficult political choices in formulating fundamental policy cannot justify letting Congress off the hook. Instead, it provides a compelling reason to require Congress, rather than its delegatee, to perform the task.

The Supreme Court's most recent encounter with the nondelegation doctrine is its decision in Whitman v. American Trucking Associations. ${ }^{74}$ In Whitman, the D.C. Circuit had remanded to the Environmental Protection Agency ("EPA") for further consideration appeals from the agency's revisions to ambient air quality standards. ${ }^{75}$ The D.C. Circuit held that the EPA had construed the relevant Clean Air Act provisions "so loosely as to render them unconstitutional delegations of legislative power." The statute under which the agency acted in promulgating the revised air standards provided that the EPA must set ozone and particulate matter standards at a level "requisite to protect the public health' with an 'adequate margin of safety.","77 The D.C. Circuit said it could not discern, for example, why the EPA revised the ozone standard down to $0.08 \mathrm{ppm}$, rather than $0.07 \mathrm{ppm}$ or some lower figure. ${ }^{78}$ According to the court, the agency "lacks ... any determinate criterion for drawing lines. It has failed to state intelligibly how much is too much." ${ }^{, 79}$ Thus, the EPA was "free to pick any point between zero and a hair below concentrations yielding London's Killer Fog." 80

Consistent with the "soft" or "reformulated" form of the nondelegation doctrine, the D.C. Circuit panel did not hold the delegation unconstitutional. Rather, it stated that because "an interpretation without the constitutional weakness is or may be available, our response is not to strike down the statute but to give the agency an opportunity to extract a

73. Id. Among others leading the revival, Justice Rehnquist cited the leading works of John HART ELy, DEMOCRACY AND Distrust, A THEORY OF JudiCIAL REVIEW 113-34 (1980) and Theodore J. Low, The END of Liberalism: Ideology, Policy, AND the Crisis of PuBLIC AUTHORITY 129-46, $297-99$ (1969). See also Ernest Gellhorn, Returning to First Principles, 36 AM. U. L. Rev. 345 (1987).

74. Whitman v. Am. Trucking Ass'ns, 2001 U.S. LEXIS 1952 (2001).

75. 175 F.3d 1027, 1033 (D.C. Cir. 1999), reh'g granted in part and denied in part, 195 F.3d 4.

76. Id. at 1034.

77. Id. (quoting 42 U.S.C. $\$ 7409$ (b)(1) (1994)).

78. Id. at 1035.

79. Id. at 1034 .

80. Id. at 1037 . 
determinate standard on its own., ${ }^{, 81}$ The court acknowledged that the remand did not serve one of the key functions of the nondelegation doctrine-ensuring that the most important social policy choices are made by Congress, not the agencies

In a unanimous opinion written by Justice Scalia, the Supreme Court reversed the D.C. Circuit's nondelegation holding. First, Justice Scalia pointed out that the D.C. Circuit had misconstrued the nondelegation doctrine by remanding the decision to the agency to give it an opportunity to formulate a determinate standard on its own. Justice Scalia declared: "We have never suggested that an agency can cure an unlawful delegation of legislative power by adopting in its discretion a limiting construction of the statute." ${ }^{82}$

After specifically reaffirming the "intelligible principle" requirement, ${ }^{83}$ Justice Scalia turned to the statutory provision itself. He found the Clean Air Act delegation "well within the outer limits of our nondelegation precedents." ${ }^{84}$ Justice Scalia concluded that directing the EPA to set a standard "requisite to protect the public health" with an "adequate margin of safety" constitutes as much, or more, congressional guidance as previous delegations that had been affirmed. ${ }^{85}$ He pointed, for example, to the delegation allowing the Attorney General to designate a drug a controlled substance if "necessary to avoid an imminent hazard to the public safety" and the direction to OSHA to "set the standard which most adequately assures, to the extent feasible, on the basis of the best available evidence, that no employee will suffer any impairment in health., ${ }^{, 86}$

It is certainly true that the Court's decision in Whitman did not breathe much new life into the nondelegation doctrine. It is also true, however, that Whitman by no means sounded the doctrine's death knell. The Court once again cited with approval the requirement that Congress itself set forth in its delegations an "intelligible principle." by rejecting the "soft" form of the doctrine espoused by the D.C. Circuit

81. Id. at 1038 (citing Int'l Union v. OSHA, 938 F.2d 1310, 1313 (D.C. Cir. 1991)).

82. Whitman v. Am. Trucking Ass'ns, 2001 U.S. LEXIS 1952, at *25 (2001).

83. Id.

84. Id. at $* 27$.

85. $I d$. at $* 30-31$.

86. Id. at *26-27 (citing Touby v. United States, 500 U.S. 160, 163 (1991) and Indus. Union Dep't, AFL-CIO v. Am. Petroleum Inst., 448 U.S. 607, 646 (1980)).

87. Id. at *4 (citing J.W. Hampton, Jr. v. United States, 276 U.S. 394, 409 (1928)). 
that would have allowed the agency to formulate a narrowing construction of the statute, in effect, the Supreme Court affirmed the underlying purpose of the doctrine. Congress itself, not the agencies, must make the fundamental policy decisions. Importantly, the Court acknowledged that it is appropriate for the courts to decide whether the nondelegation doctrine has been violated, even as the Court left little doubt that courts should tread very gingerly. ${ }^{88}$

In sum, the Whitman decision does not foreclose the possibility that nondelegation challenges can be successfully (if only rarely) mounted in the future. A challenge to a delegation as indeterminate as the "public interest" standard ought to be one of those rare cases with a chance for success. As discussed in the next section, however, after Whitman, it is unlikely that, even in this instance, the courts will force Congress to do its job anytime soon.

\section{THE PUBLIC INTEREST STANDARD: AN INDETERMINATE DELEGATION THAT CONSTITUTES AN ABDICATION OF CONGRESSIONAL RESPONSIBILITY}

Not surprisingly, in most serious discussions of the nondelegation doctrine, courts or commentators cite the 1934 Act's public interest standard (sometimes as an aberration) to show the outer reaches of the nondelegation doctrine. For example, in Mistretta v. United States, Justice Scalia exclaimed that it is difficult to imagine any standard "too vague to survive judicial scrutiny" when the public interest standard has been upheld. $^{89}$ In Whitman, Justice Scalia once again cited the public interest standard as an indication of how far the Court has been willing to go in

88. Id. at $* 26$. Justice Scalia declared that "[w]hether the statute delegates legislative power is a question for the courts. ..." Id. At the same time, however, he quoted from his dissenting opinion in Mistretta v. United States, in which he stated that the Court "almost never felt qualified to second guess Congress" regarding the scope of the delegation. Id. at *29 (quoting 488 U.S. 361, 416 (1989)). In Mistretta, Justice Scalia also stated that the nondelegation doctrine is "not an element readily enforceable by the courts." 488 U.S. at 415. Somewhat incongruously, at the same time, he declared: "It is difficult to imagine a principle more essential to democratic government than that upon which the doctrine of unconstitutional delegation is founded: Except in a few areas constitutionally committed to the Executive Branch, the basic policy decisions governing society are to be made by the Legislature." Id.

89. Mistretta, 488 U.S. at 416 (Scalia, J., dissenting) (citing NBC, Inc. v. United States, 319 U.S. 190, 216-17 (1943); N.Y. Cent. Sec. Corp. v. United States, 287 U.S. 12, 24-25 (1932)). 
sustaining broad delegations. ${ }^{90} \mathrm{He}$ did so without giving any indication that the Court is reconsidering such "outer limits" decisions."

Despite the fact that the Court has continued to refer with approval to its decades-old affirmance of the public interest standard, in light of the standard's sheer indeterminateness, commentators have continued to urge that courts revisit its lawfulness. David Schoenbrod, a scholar at New York Law School who has written widely on the subject, urged a revival of the strong form of the nondelegation doctrine, noting that the public interest standard says "practically nothing at all" about Congress's goals in the 1934 Act. $^{92}$ Noted administrative law scholar Ernest Gellhorn, after pointing out that Article I provides that "[a]ll legislative [p]owers" be vested in Congress, ${ }^{93}$ argued that "[s]tatutes that allow administrators to determine what is in the 'public interest, convenience or necessity' simply fail as exercises of that power . . because they leave basic normative issues unanswered and thus within the realm of the delegate." $" 94$

Likewise, Gary Lawson, a constitutional law scholar at Northwestern University School of Law, identified the public interest standard as "easy kill number one" in terms of statutory provisions that should be struck down on nondelegation grounds. This is because the licensing provisions of the 1934 Act grant "nearly absolute discretion about a subject that is absolutely central to the regulation of broadcasting."

Lawson's characterization of the public interest standard as "easy kill number one" may be hyperbolic, because killing it would require that the the $N B C$ decision be overruled. ${ }^{96}$ Given the history of the ups and downs of the nondelegation doctrine, however, and the radically changed landscape of the communications industry - as compared to seventy years ago-it is not totally unrealistic to suggest that the doctrine might not survive another

90. Whitman v. Am. Trucking Ass'n, 2001 U.S. LEXIS 1952 at $* 28$ (2001) (citing NBC, Inc., 319 U.S. at 225-226).

91. See supra note 84 and accompanying text.

92. David Schoenbrod, Power Without Responsibility: How Congress Abuses the People Through Delegation 100 (1993).

93. Gellhorn, supra note 73, at 347 (quoting U.S. ConsT. art. I, § 1).

94. Id. at 347.

95. Gary Lawson, Delegation and the Constitution, 22 REg., No. 2, 1999, at 23, 29, available at $\mathrm{http}: / / \mathrm{www} . c a t o . o r g / p u b s /$ regulation/regv22n2/delegation.pdf (last visited Apr. 2 , 2001). While Lawson mentions only broadcasting, as pointed out earlier, the public interest standard is broadly applicable to the regulation of the telephone and other telecommunications sectors.

96. See infra notes 101-02 and accompanying text. 
brush with judicial scrutiny. Acknowledging the existence of a much more competitive telecommunications environment, however, Congress need not wait for another constitutional test. Rather, in the context of formulating a new deregulatory regime more suited to today's realities, it should replace this indeterminate standard with more specific criteria.

To appreciate fully why Congress should replace the current standard, it is useful to examine the origin of the public interest standard in the communications industry context, and then to identify some of the ways the FCC has exercised the broad discretion under the standard to implement its regulatory programs. A review of the legislative history of the 1934 Act shows that when Congress included the "public interest, convenience, and necessity" phraseology (and its various permutations), it had not adopted a singular, agreed-upon meaning - certainly not one relevant to today's environment. ${ }^{97}$

The first use of the "public interest" standard in federal legislation occurred in the Federal Transportation Act of 1920, which amended the Interstate Commerce Act. ${ }^{98}$ The "public interest" phrase was imported into the federal statute from an Illinois railroad statute, ${ }^{99}$ which acquired the phraseology from the Supreme Court's 1876 decision in Munn v. Illinois. ${ }^{100}$ In Munn, which involved state regulation of grain storage elevators, the Court held that states lawfully "may regulate the use of private property when such use was 'affected with a public interest." the public interest language from old common carriage cases invoking the common-law public utility concepts of reasonableness and nondiscrimination. ${ }^{102}$

When Congress enacted the Radio Act of 1927 ("1927 Act") and created the Federal Radio Commission to regulate use of the radio spectrum, it incorporated the public interest standard into the statute. ${ }^{103}$ Congress may have intended the inclusion of the standard to give the new

97. See supra note 6 and accompanying text.

98. Erwin G. Krasnow \& Jack N. Goodman, The "Public Interest" Standard: The Search for the Holy Grail, 50 FED. COMM. L.J. 605, 610 n.19 (1998) (citations omitted).

99. Id.

100. 94 U.S. 113,126 (1876).

101. Krasnow \& Goodman, supra note 98 , at $610 \mathrm{n} .19$.

102. Munn, 94 U.S. at $126-28$.

103. Radio Act of 1927 , ch. 169,44 Stat. 1162,1162 , repealed by Communications Act of 1934, ch. 652, § 602(a), 48 Stat. 1064, 1102 (codified as amended in scattered sections of 47 U.S.C.). 
commission broader regulatory authority over radio than that which the courts previously had held the Secretary of Commerce to possess. It is generally agreed, however, that not only did the statute fail to define the standard's intended meaning, but even the legislative history provides little guidance as to what degree of authority Congress meant to give the new agency. ${ }^{104}$

To the extent one can glean anything at all from the legislative history, it is this: Some legislators entertained notions that the new radio industry should be regulated like a public utility, with nondiscrimination requirements and rate regulation. They may have equated the public interest standard with traditional common carriage requirements applicable to the then "public utilities," such as telephone companies, power companies, water companies, and the railroads. Still, the link, if any, between the "public interest" standard and the "public utility" concepteven as then understood-remained ill-defined.

Thus, in a section of the House Report accompanying the 1927 Act, the committee stated:

Although persons or concerns engaging in the business of radio communication, including broadcasting, for hire, are concededly public utilities, and should be regulated as such, yet there are no provisions in this bill providing for such regulation. There is nothing in the existing radio law or in this bill to regulate or to require equal treatment.

... Secretary Hoover recognizes and speaks of parties rendering a radio communication for hire as public utilities; and the previous committee reports have so recognized and designated them.

... [O]fficials of the Radio Corporation of America have a monopoly in radio communication between this and foreign countries and state that it is a public utility; that the protection of the public lies in regulation of rates, service, etc., and they have no objection to such regulation.

Similarly, regarding the regulation of radio, the Senate Committee report contains language that calls to mind common carriage principles, without explicitly tying those principles to the public interest standard: "[I]f any broadcasting station is used for hire or by political candidates or for

104. See, e.g., Krasnow \& Goodman, supra note 98, at 609-11.

105. House Comm. ON the Merchant Marine AND Fisheries, 69th CONG., RePort to ACCOMPANY H.R. 9971 (2d Sess. 1926) (emphasis added), reprinted in 3 BERNARD SChWARTZ, The ECONOMIC REgulation of Business and INDUSTRY: A Legislative HISTORY OF U.S. REGULATORY AGENCIES 2110 (1973). 
discussing public questions, there shall be no discrimination and the licensee of such station shall be deemed a common carrier in interstate commerce." 106

Because the legislative history of the 1927 Act failed to provide any real meaning for the public interest standard, the statute as adopted did not impose common carrier obligations on broadcasters. As Senator Dill, the leading proponent of the legislation in the Senate, explained, "it seemed unwise to put the broadcaster under the hampering control of being a common carrier and compelled to accept anything and everything that was offered him so long as the price was paid."107 Further disproving the usefulness of some rhetoric in the legislative history suggesting a possible link between the public interest standard and common law common carrier concepts, "common carrier" was defined in the 1934 Act specifically to exclude "a person engaged in radio broadcasting.,"108

Indeed, the 1934 Act simply incorporated the public interest standard from the 1927 Act without any relevant changes (for the purposes of this Article) and without any meaningful elucidation in the legislative history. ${ }^{109}$ Thus, search as one might through the legislative history, no one really can contradict Professor Robinson's verdict: "What the act itself does not define, the legislative history does not illuminate." ${ }^{" 10}$ Nor can anyone challenge his subsequent conclusion: "Plainly the 'public interest' phrase is one of those atmospheric commands whose content is as rich and variable as the legal imagination can make it according to the circumstances that present themselves to the policymaker (under the supervision of the courts,

106. Senate Comm. on Interstate Commerce, Regulation of Radio Transmission, 69TH CONG., REPORT TO ACCOMPANY H.R. 9971 (2d Sess. 1926), reprinted in ScHWARTZ, supra note 105 , at 2120.

107. 67 CONG. REC. 12,502 (1926).

108. 47 U.S.C. $\$ 153($ h) (1994).

109. See Thomas W. Hazlett, Physical Scarcity, Rent Seeking, and the First Amendment, 97 Colum. L. Rev. 905, 924 n.72 (1997) ("The law governing broadcast licensing was crafted in the Radio Act of $1927, \ldots$. which was repeated virtually verbatim in the Communications Act of 1934."). The provisions relating to regulation of common carriers, for the most part, simply tracked the provisions of the Interstate Commerce Act applicable to communications. S. REP. No. 73-781, at 3 (1934).

110. Robinson, supra note 6 , at 14 . One thing the legislative history does illuminate is that the existing broadcasters strongly favored a public interest standard because they believed-correctly, it turned out, at least up to now-that the inclusion of such a standard would provide a constitutional justification for the new regulatory agency to exclude new entrants. See Hazlett, supra note 122, at 930-32. 
of course)."111

Even the agency charged with administering the standard quickly concluded that it was "manifestly impossible" to foresee all the various regulatory potentialities. ${ }^{112}$ The year after its creation, the Federal Radio Commission conceded that, in light of the absence of statutory definition of the "public interest," "[t]he phrase will have to be defined by the United States Supreme Court, and that will probably be done by a gradual process of decisions on particular combinations of fact." ${ }^{\prime 13}$

Perhaps early on, the courts might have interpreted the "public interest" language in a way that at least required the agency to give it some principled and confined meaning (although this approach-like the D.C. Circuit's approach which was ultimately rejected by the Supreme Court in the American Trucking case ${ }^{114}$-would not have responded to the true purpose of the nondelegation doctrine). Rather, in tune with the New Deal jurisprudence giving the new regulatory agencies wide berth after the "switch in time that saves nine," gave the public interest standard an expansive interpretation. ${ }^{116}$ In $F C C v$. Pottsville Broadcasting Co., Justice Frankfurter, obviously somewhat in awe of what he called the "new and far-reaching science of broadcasting," $" 17$ declared that the public interest standard "is as concrete as

111. Robinson, supra note 6 , at 16 . To illustrate the extent to which at least some legislators recognized the vagueness inherent in the standard, Professor Robinson cited a colloquy in which Senator Cummins argued against judicial review of FCC decisions. 67 CONG. REC. 12,355 (1926), quoted in Robinson, supra note 6, at 16 n.62. Senator Cummins contended that in a licensing matter, for example, there would be no basis for a judicial challenge because there would be "no law, no regulation ... nothing that would indicate to the commission how it ought to decide the matter unless [it be inferred] that it is to be decided in the public interest." Id.

112. Statement Made by the Commission Relative to the Public Interest, Convenience, or Necessity, 2 FRC ANN. REP. 166 (1928), reprinted in FRANK J. KAHN, DOCUMENTS OF AMERICAN BROADCASTING 57, 59 (4th ed. 1984).

113. Id.

114. See supra note 94 and accompanying text.

115. LuCAS A. Powe, JR., The WarRen Court and American Politics 4 (2000).

116. In the first case interpreting the public interest standard, the Court upheld a Federal Radio Commission decision awarding a license on a comparative basis. Fed. Radio Comm'n v. Nelson Bros. Bond \& Mortgage Co., 289 U.S. 266 (1933). The Court said the criterion is to be "interpreted by its context, by the nature of radio transmission and reception, by the scope, character and quality of services, and, where an equitable adjustment between States is in view, by the relative advantages in service which will be enjoyed by the public through the distribution of facilities." Id. at 285.

117. 309 U.S. 134,137 (1940). 
the complicated factors for judgment in such a field of delegated authority permit." "18

Justice Frankfurter put the Court's affirmation of the public interest standard into the context of contemporary thinking, remarking upon "the felt need of governmental supervision over economic enterprise-a supervision which could effectively be exercised neither directly through self-executing legislation nor by the judicial process." 119 Therefore, in effect, under this regime, it was acceptable-even desirable-for neither Congress nor the courts to have any real responsibility for constraining the agency's promulgation of fundamental social and economic policies.

Quoting Elihu Root, Justice Frankfurter acknowledged that allowing administrative agencies to act under such vague delegations of authority invested them with tremendous power, but he embraced this new development with unabashed relish:

There will be no withdrawal from these experiments. We shall go on; we shall expand them, whether we approve theoretically or not, because such agencies furnish protection to rights and obstacles to wrong doing which under our new social and industrial conditions cannot be practically accomplished by the old and simple procedure of legislatures and courts as in the last generation.

Justice Frankfurter was correct that the law, at least for a substantial period of time and "theoretical" niceties aside, was headed toward expansion of these "experiments" with indeterminate delegations. Indeed, perhaps to avoid unnecessarily fomenting resistance to the experiments, Frankfurter refrained from quoting the passage immediately preceding the sentence from Root that appears above: "Before these agencies the old doctrine prohibiting the delegation of legislative power has virtually retired from the field and given up the fight."121

To confirm the public interest standard's lack of any real meaning, one need only look at Justice Roberts's opinion for a unanimous court in

118. Id. at 138 .

119. Id. at 142 .

120. Id. at 142 n.4 (quoting Elihu Root, in 41 A.B.A. REP. 355, 368-69 (1916)).

121. 41 A.B.A. REP. at 368. James Landis, Justice Frankfurter's former colleague on the Harvard Law School faculty and another leading proponent of "expert" agencies, put it equally as bluntly: Administrative agencies must be granted "all necessary powers" and we must "not [be] too greatly concerned with the extent to which such action does violence to the traditional tripartite theory of government organization." JAMES M. LANDIS, THE ADMINISTRATIVE PROCESS 12 (1938). 
FCC v. Sanders Brothers Radio Station, ${ }^{122}$ decided just two months after Pottsville. In Sanders Brothers, the Court agreed with the FCC that the agency need not consider economic injury to an existing licensee in deciding, under the public interest standard, whether to award a license to a rival station. ${ }^{123}$ In doing so, however, the Court used language that, if read consistent with ordinary usage, would give the delegation a considerably narrower cast: "But the Act does not essay to regulate the business of the licensee. The Commission is given no supervisory control of the programs, of business management or of policy." 124

Suffice it to say, Justice Frankfurter's more expansive view of the delegated authority prevailed. While one might argue that the FCC has remained true to Justice Roberts's formulation in some extremely literal sense, the fact of the matter is that, over the years under the public interest rubric, the FCC has, heavily supervised program-content decisions and other aspects of broadcast station management and policy. This supervision has run the gamut, from dictating the types of programming that licensees must carry, to ordaining the type of records that stations must keep in public files, to defining the permissible hiring practices of the station. So, notwithstanding Justice Roberts's view, the agency, in fact, has stretched its public interest authority to assert "supervisory control" over many aspects of the business affairs of companies in various-telecommunications sectors.

For example, the FCC recently issued an Order requiring broadcasters and multichannel video programming distributors to provide a specified amount of programming with narrated "video descriptions" to make television more accessible to the visually impaired. ${ }^{125}$ The FCC relied, in part, on its public interest authority in imposing this new regulatory requirement. ${ }^{126}$ Putting aside the apparent well-intentioned purpose of this new regulation, ${ }^{127}$ the FCC's exercise of public interest authority in this instance seems even more ill-advised, because it comes in the face of

122. 309 U.S. 470 (1940).

123. Id. at 473 .

124. Id. at 475 .

125. Implementation of Video Description of Video Programming, Report and Order, 15 F.C.C.R. 15,230 para. 1, 21 Comm. Reg. (P \& F) 904 (2000).

126. Id. paras. $54,58$.

127. While the Commission's Order minimized the divergence of views within the blind community concerning the desirability of requiring described programming, the National Federation of the Blind filed comments opposing the mandate. Id. (separate statement of Comm'r Michael K. Powell, concurring in part and dissenting in part). 
strong indications that Congress intended to reserve the decision to itself whether narrated video descriptions should be mandated. ${ }^{128}$

In addition to a continuous stream of decisions affecting the program content of broadcast stations from the earliest days of the agency ${ }^{129}$ to the present, ${ }^{130}$ the FCC has employed the public interest standard to regulate the industry structure of broadcasting and other telecommunications sectors. ${ }^{131}$ The standard also has served as the underpinning for regulation of employment practices of the Commission's regulatees as well. ${ }^{132}$

The FCC regularly relies on the public interest standard in the context of passing on license transfer applications to regulate company-specific business practices that more appropriately should be addressed, if at all, on an industrywide basis in a generic rulemaking proceeding. Because of the standard's indeterminate nature, it is particularly susceptible to use as an open-ended bargaining chip by the FCC to extract "voluntary" commitments from merger applicants that go beyond existing statutory requirements or the FCC's own rules. ${ }^{133}$ No one can dispute that much of

128. See id. at n.21 (separate statement of Comm'r Michael K. Powell, concurring in part and dissenting in part).

129. In the FRC initial statement delineating how broadcasters should meet their public interest obligations, the agency listed the following criteria, among others: too much program duplication should be avoided; advertising should be incidental to the main object of a program; programming should not be of a "distinctly private nature;" and programming should be broadcast on a regular schedule so listeners know when to tune in. Statement Made by the Commission Relative to the Public Interest, Convenience, or Necessity, 2 FRC ANN. REP. 166 (1928), reprinted in KAHN, supra note 112, at 60-61.

130. Pub. Interest Obligations of TV Broad. Licenses, Notice of Inquiry, 14 F.C.C.R. 21,633 (1999) (considering public interest requirements, ranging from whether broadcasters should be required to carry free campaign ads to whether they should be required to carry weather forecasts targeted on a neighborhood level).

131. The FCC's various policies relating to diversity of control of the mass media largely have rested on its public interest authority. See, e.g., FCC v. Nat'l Citizens Comm. for Broad., 436 U.S. 775 (1978) (affirming FCC rule prohibiting certain broadcast station/daily newspaper cross-ownerships). The FCC has also used its public interest authority to regulate the industry structure of the commercial mobile services industry. See, e.g., Regulatory Treatment of Mobile Services, Third Report and Order, 9 F.C.C.R. 7988, para. 15, 76 Rad. Reg.2d (P \& F) 326 (1994) (imposing a cap on the amount of CMRS spectrum a licensee may aggregate in a given geographic area).

132. See, e.g., Review of the Comm'n's Broad. and Cable Equal Employment Opportunity Rules and Policies, Notice of Proposed Rulemaking, 13 F.C.C.R. 23,004 (1999).

133. See, e.g., Ameritech Corp. \& SBC Comm. Inc., supra note 6 (imposing thirty separate regulatory conditions under its public interest authority, many of which had nothing to do with the particular issues raised by the license transfer application). For example, the condition requiring that the merged entity provide a certain percentage of advanced services 
the significant regulatory activity of the FCC takes place under the rubric of the public interest delegation, rather than more specific legislative guidance.

\section{CONCLUSION: A NEW DEREGULATORY PARADIGM REQUIRES A NEW MEASURE OF CONGRESSIONAL ACCOUNTABILITY}

Strictly speaking, the public interest standard may have been no less constitutionally suspect at the time of its inclusion in the original 1934 Act than today. The "felt need" for the standard, however, to use Justice Frankfurter's words, ${ }^{134}$ at least reflected the temper of the times and the early communications industry environment. After all, the telephone and radio businesses, the two principal targets of public interest regulation, were still in their developmental stages and relatively immune from meaningful competition.

The willingness of Congress to hand off responsibility to a new "expert" alphabet agency to regulate these new industries under a vague standard perhaps is not surprising. Justice Frankfurter's declaration that the public interest standard "is as concrete as the complicated factors for judgment in such a field of delegated authority permit" ${ }^{\text {,135 }}$ may have been consonant with the conventional wisdom of the time. The standard surely turned out to be the "supple instrument" in the hands of the agency that Frankfurter envisioned. ${ }^{13}$

to low-income neighborhoods involves the type of policy issue that should be considered in a generic rulemaking proceeding. If a mandate to serve certain areas differentially makes sense as sound policy, then it should be applicable to all similarly situated local exchange companies, not just those that happen to file license transfer applications. The same is true for the condition applied uniquely to the merged company, under which it must establish a separate subsidiary for providing certain data services. Other similarly situated local exchange companies have been exempted from establishing such subsidiaries. For other recent mergers in which the FCC has imposed unique conditions on the merger applicants, see Applications of WorldCom, Inc. and MCI Comms. Corp. for Transfer of Control of MCI Comms. Corp. to WorldCom, Inc., Memorandum Opinion and Order, 13 F.C.C.R. 18,025 paras. 7-14, 13 Comm. Reg. (P \& F) 477 (1998); Applications of NYNEX Corp., Transferor, and Bell Atl. Corp., Transferee, for Consent to Transfer Control of NYNEX Corp. and its Subsidiaries, Memorandum Opinion and Order, 12 F.C.C.R. 19,985 paras. 2736, 9 Comm. Reg. (P \& F) 187 (1997).

134. FCC v. Pottsville Broad. Co., 309 U.S. 134, 142 (1940); see supra note 129 and accompanying text.

135. Pottsville Broad. Co., 309 U.S. at 138.

136. Id. 
Today, the communications environment is radically changed, with competitive alternatives taking root in all sectors, even as these sectors continue to evolve, converge, and reemerge in new forms and new businesses. In part, the FCC itself deserves substantial credit for taking steps from the early 1980s onward, such as in the Competitive Carrier and Computer II proceedings, to encourage the development of competition. ${ }^{137}$ The Commission took a series of deregulatory steps over many years before enactment of the Telecommunications Act of 1996 ("1996 Act"), at which point the FCC faced many challenges to its authority to encourage new market entrants. Congress deserves substantial credit for moving in a pro-competitive direction in the 1996 Act. The fact that the pace of change, with the rapid development of digital processing, fiber-optics, new wireless devices, and other technologies, may have spurred regulators and legislators to act, does not diminish the importance of the earlier deregulatory steps.

Now, though, Congress must ask itself anew whether the public interest standard is indeed sufficiently "concrete" to fulfill Congress's responsibility to set communications policies for the Information Age, or whether it is so vague that it can mean whatever three FCC Commissioners say it means on any given day. Hypothetically, under the public interest standard, one set of three commissioners could determine this year that the public interest requires that, sixty days before an election, broadcasters must make available one hour a day of free air time for campaign commercials, while next year another three (or the same three) may decide otherwise. ${ }^{138}$ In light of the recent spate of school shootings, three

137. See, e.g., Policy and Rules Concerning Rates for Competitive Common Carrier Services and Facilities Authorizations, Notice of Inquiry and Proposed Rulemaking, 77 F.C.C.2d 308 (1979); First Report and Order, 85 F.C.C.2d 1, 52 Rad. Reg.2d (P \& F) 215 (1980); Further Notice of Proposed Rulemaking, 84 F.C.C.2d 445 (1981); Second Report and Order, 91 F.C.C.2d 59, 52 Rad. Reg.2d (P \& F) 187 (1982); Further Notice of Proposed Rulemaking, 47 Fed. Reg. 17,308 (1982) ("Competitive Carrier Proceeding"). See also Amendment of Section 64.702 of the Comm'n's Rules and Regulations (Second Computer Inquiry), Final Decision, 77 F.C.C.2d 384, 44 Rad. Reg.2d (P \& F) 669 (1980); Memorandum Opinion and Order, 84 F.C.C.2d 50, 48 Rad. Reg.2d (P \& F) 1107 (1980); Memorandum Opinion and Order on Further Reconsideration, 88 F.C.C.2d 512, 50 Rad. Reg.2d (P \& F) 629 (1981); Computer and Comms. Indus. Ass'n v. FCC, 693 F.2d 198 (D.C. Cir. 1982); La. Pub. Serv. Comm'n v. FCC, 461 U.S. 938 (1983) ("Computer II" proceeding).

138. Under the Administrative Procedure Act, 5 U.S.C. $\$ 706$ (2)(A) (1994), the agency's decisions must not be "arbitrary and capricious," and the agency must provide a reasoned basis when it departs from prior agency precedent. Motor Vehicle Mfrs. Ass'n v. State Farm Auto. Ins. Co., 463 U.S. 29 (1983). These constraints do help ensure reasoned 
commissioners could decide that the public interest requires an hour per day of teen-oriented educational programming, and three others (or the same three) may decide that all "violent" shows may be broadcast only after 10:00 p.m. Three commissioners could mandate that licensees broadcast one hour of programming a week that truly reflects the diversity of American culture. Those same three, or a different three, may then announce a definition of "diversity" or "American culture." When Congress delegates authority, there must be some more "intelligible principle" at work than the rule of three. ${ }^{139}$

Congress should take a number of actions in light of the rise of competition across industry sectors, coupled with the FCC's reluctance to loosen regulatory constraints commensurate with the changed environment. Congress should adopt new legislation with more specific deregulatory direction sooner rather than later. It should consider establishing sunset dates for much of the most intrusive regulation that now applies uniquely to services provided by incumbent telephone companies, especially broadband services. At the same time, it should mandate that comparable competitive broadband services provided by cable, satellite, wireless, and other providers remain free of regulatory constraints. It should reform the universal service system to make subsidy flows much more explicit and targeted to those who truly need financial assistance. Finally, it should move towards a regime that creates and recognizes more secure property rights in spectrum so that efficiency and innovation in the use of this resource will be fostered.

If Congress fails to provide more specific policy guidance for the

decisiomaking, and they are important, but they do not prevent the agency from changing its mind in the exercise of delegated lawmaking authority. See Chevron U.S.A., Inc. v. Natural Res. Def. Council, 467 U.S. 837 (1984). At issue here is not the rationality of the agency's decisions under the public interest delegation, but the very lawfulness of the delegation itself.

139. In response to the argument here, at least with respect to regulation of the mass media, one may contend that sensitivity to First Amendment concerns dictates that Congress need not be more specific in its delegation. In other words, some argue that it would be inappropriate, consistent with the First Amendment, for Congress to set forth more specific guidance concerning the types of programming the agency should mandate. Apart from the dubious reasoning of Red Lion Broadcasting Co., Inc. v. FCC, 395 U.S. 367 (1969), at the time it was decided, in today's environment (and putting aside certain well-recognized exceptions), the First Amendment likely precludes either Congress or the Commission from adopting requirements that affect program content for any electronic media. The completely indeterminate nature of the public interest delegation, however, raises separate constitutional concerns. 
authority it delegates to the Commission, the possibility exists, however remote, that in the future the courts may call Congress to task. As shown above, in recent years there has been at least somewhat more willingness on the part of courts to entertain nondelegation claims, and more willingness on the part of commentators to argue vigorously for the doctrine's revival.

Absent congressional initiative, the courts may conclude that, in a representative democracy, with the separation of powers squarely at its foundation, it is not too much to ask that lawmakers assume responsibility for making the most fundamental and basic policy judgments. This does not mean, at least from a constitutional perspective, that such judgments may not remain somewhat general. A delegation at a rather high level of generality, however, is far better than a delegation that provides no meaningful guidance at all.

To properly regulate an industry as important to the economic and social fabric of the nation as the communications industry, Congress should revise the 1934 Act to lay down sufficiently concrete guidance to give the public a basis on which to hold its representatives accountable. In other words, Congress should take it upon itself to revise the 1934 Act to replace the indeterminate public interest standard with more specific fundamental policy guidance tailored to the new competitive communications environment. 


\section{APPENDIX A \\ THE "PUBLIC INTEREST" STANDARD \\ IN THE COMMUNICATIONS ACT}

\section{TITLE I - General Provisions}

§ 7(a) [47 U.S.C. § 157] - "inconsistent with the public interest"

The burden of proof under which complaints against permitted new technologies will be reviewed (promoting the goal of encouraging new technology and services).

§ 7(b) [47 U.S.C. § 157] - "the public interest"

The standard by which the Commission shall determine the qualities of new technology applications.

§ 8(d)(2) [47 U.S.C. § 158] - "the public interest"

The standard by which the Commission may waive application fees in any specific instance.

§ 9(b)(1) [47 U.S.C. § 159] - "the public interest" fees.

One of the factors by which the Commission may derive regulatory

§ 9(d) [47 U.S.C. § 159] - "the public interest"

The standard by which the Commission may waive or defer a regulatory fee.

§ 10(a)(3) [47 U.S.C. § 160] - "the public interest"

One of the factors that may lead the Commission may forbear from regulation.

§ 10(b) [47 U.S.C. § 160] - "the public interest"

Clarification that the public interest determination in $\S 10(a)(3)$ may be achieved upon a finding that forbearance will promote competition among providers of telecommunications services. 
$\S 11(a)(2)$ [47 U.S.C. § 161] - "necessary in the public interest"

The standard of review for determining the necessity of all regulations during biennial review for regulatory reform.

§ 11(b) [47 U.S.C. § 161] - "the public interest"

The standard of review for determining the necessity of all regulations during biennial review for regulatory reform.

\section{TITLE II - Common Carriers}

§ 201(a) - "the public interest"

One part of the general duties of common carriers.

$\S 201$ (b) - "the public interest"

The standard of review for Commission interference with a carrier's business dealings with a non-carrier.

$\S 201(b)$ - "necessary in the public interest"

The standard for the primary authority by which the Commission may prescribe rules and regulations for common carriers generally.

$\S 214(\mathrm{a})$ - "public convenience and necessity require"

The standard by which the Commission certifies carriers to construct new lines or extend existing lines.

$\S 214(c)$ - "the public convenience and necessity"

The standard by which the Commission shall determine which proposed new construction is granted a certificate and derive the powers to attach terms and conditions to that certificate.

$\S 214(\mathrm{~d})$ - "in the interest of public convenience and necessity"

The standard by which the Commission may authorize or require common carriers to add lines or a public office.

\footnotetext{
* Section numbers refer to both the Communications Act and Title 47 of the United States Code, unless otherwise indicated.
} 
$\S 214(\mathrm{e})(2)$ - "with the public interest, convenience, and necessity"

The standard by which State commissions must decide which local carrier(s) are to receive universal service funding.

\section{$\S 215(\mathrm{a})$ - "the public interest"}

The standard by which the Commission may promulgate regulations for the review of transactions for equipment or service.

$\S 220(\mathrm{~h})$ - "the public interest"

The standard by which the Commission may classify different types of carriers and set different requirements for the different classes.

$\S 229(\mathrm{e})(2)$ - "the public interest"

One part of the standard by which the Commission may allow recovery of costs of service provided to law enforcement.

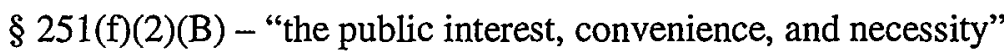

One part of the standard by which State commissions may grant petitions for exemption, suspension, or modification of application requirements for provision of rural local exchange service.

$\S 251(\mathrm{~h})(2)(\mathrm{C})$ - "the public interest, convenience, and necessity"

One part of the standard by which the Commission may determine which carriers to define as incumbent local exchange carriers.

$\S 252(\mathrm{e})(2)(\mathrm{A})(\mathrm{ii})$ - "the public interest, convenience, and necessity"

One of the standards by which a State commission may reject a negotiated agreement between carriers. (State commission approval is required.)

$\S 254(b)(7)$ - "the public interest, convenience, and necessity"

One of the enumerated principles by which the Commission and the Joint Board shall implement universal service policies. (This is the catchall provision.) 
$\S 254(c)(1)(D)$ - "public interest, convenience, and necessity"

One factor by which the Commission shall define which services to support under federal universal service support mechanism.

§ 254(d) - "the public interest"

The standard by which the Commission may require telecommunications carriers, other than those specifically enumerated, to contribute to universal service support.

$\$ 257(b)$ - "the public interest, convenience, and necessity"

One part of the standard by which the Commission is to complete a proceeding to eliminate barriers to market entry.

$\S 257(c)(1)$ - "the public interest, convenience, and necessity"

The standard by which the Commission shall periodically review and report to Congress on barriers to market entry.

$\S 257(c)(2)$ - "the public interest, convenience, and necessity"

The standard by which the Commission shall eliminate inconsistent regulations discovered during periodic reviews for barriers to market entry.

$\S 259$ (b)(1) - "the public interest"

One part of the standard restricting how the Commission may regulate the sharing of public switched network infrastructure.

$\S 271(\mathrm{~d})(3)(\mathrm{C})$ - "the public interest, convenience, and necessity" One part of the standard by which the Commission shall approve or deny a $\S 271$ application.

$\S 272(f)(3)$ - "public interest, convenience, and necessity"

The standard by which the Commission shall prescribe rules, despite this section's provisions that discontinue restrictions on ILECs three years after interLATA service is allowed. 
$\S 276(\mathrm{~b})(1)(\mathrm{D})$ - "the public interest"

The standard by which the Commission may regulate Bell Operating Companies differently than other payphone operators in instruction for rulemaking to fairly compensate payphone providers for service.

$\S 276(b)(2)-"$ "public interest payphones"

Standard by which the Commission shall determine placement of public interest telephones. Standard where there would otherwise not be a payphone.

\section{TITLE III - Radio}

$\S 302(a)$ - "the public interest, convenience, and necessity"

One part of the standard by which the Commission may generally exercise rulemaking power over broadcasting. (There is also a reasonableness standard.) (repealed June 5, 1936)

$\S 303$ - "as public interest, convenience, or necessity requires"

The standard by which the Commission may exercise its general powers to classify, license, and regulate radio.

$\S 303(f)$ - "promote public convenience or interest or will serve public necessity"

One part of the standard by which the Commission may change a station's broadcasting frequency.

$\S 303(\mathrm{~g})$ - "in the public interest"

The standard by which the Commission must study new and uses for radio.

$\S 307$ (a) - "if public convenience, interest, or necessity will be served"

The standard by which the Commission shall grant radio broadcast licenses. 

served"

$\S 307(c)(1)-$ "public interest, convenience, and necessity will be licenses.

The standard by which the Commission shall grant and renew radio

$\S 307(e)(1)$ - "serves the public interest, convenience, and necessity"

The standard by which the Commission may authorize certain types of radio broadcasting without a license. served"

$\S 309$ (a) - "the public interest, convenience, and necessity will be

The standard by which the Commission shall review license applications for radio broadcast.

$\S 309(f)$ - "in the public interest"

The standard by which the Commission may grant temporary licenses to avoid service delay.

$\S 309(j)(3)$ - "the public interest"

One of the standards by which the Commission shall develop a competitive bidding system for spectrum allocation.

$\S 309(\mathrm{j})(4)(C)$ - "public interest, convenience, and necessity"

One part of the standard by which the Commission shall promulgate regulations for a competitive spectrum allocation bidding system.

$\S 309(j)(6)(E)-$ "in the public interest"

Affirmation of the Commission's duty to act in the public interest with respect to competitive bidding system.

$\S 309(j)(7)(A)-$ "public interest, convenience, and necessity"

Prohibition against the Commission basing a $\S 303$ license application determination in the public interest on expected Federal revenues from a competitive bidding system. 
$\S 309(\mathrm{j})(7(\mathrm{~B})$ - "public interest, convenience, and necessity"

The standard by which the Commission shall formulate rules for a competitive bidding system requiring that they are not solely or predominately designed with the expectation of federal revenues.

$\S 309(\mathrm{k})(1)(\mathrm{A})$ - "served the public interest, convenience, and necessity"

One part of the standard by which the Commission may renew broadcast licenses.

$\S 309(\mathrm{k})(4)$ - "the public interest, convenience, and necessity"

Prohibition against consideration of competitors when the Commission reviews the public interest in renewal applications.

$\S 310(b)(4)$ - "public interest will be served"

One part of the standard by which the Commission shall deny or revoke broadcast licenses to foreign owned or controlled entities.

$\S 310$ (d) - "the public interest, convenience, and necessity"

The standard by which the Commission may restrict or limit transfers of station licenses and construction permits.

$\S 311(\mathrm{~b})$ - "the public interest, convenience, or necessity"

One part of the standard by which the Commission may choose the location of station application hearings.

$\S 311(c)(3)$ - "the public interest, convenience, or necessity"

One part of the standard by which the Commission may approve agreements between competing license applicants for one applicant to withdraw its application.

$\S 311(d)(3)$ - "public interest, convenience, or necessity"

One part of the standard by which the Commission may approve agreements between competing construction permit applicants for an applicant to withdraw its application. 
$\S 315(a)(4)$ - "in the public interest"

Affirmation of a broadcaster's duty to act in the public interest despite a choice not to provide airtime to political candidates.

$\S 316(a)(1)-$ "public interest, convenience, and necessity"

The standard by which the Commission may require modification of construction permits.

$\S 317$ (d) - "public interest, convenience, or necessity"

The standard by which the Commission may waive certain cases or classes of cases from announcing that the broadcast programming has been paid for by a third party.

$\S 318$ - "the public interest, convenience, or necessity"

The standard by which the Commission may waive or modify the station operator license requirements.

$\S 319$ (c) - "the public interest"

One part of the standard by which the Commission shall grant a station license upon successful completion of construction under permit.

§ 319(d) - "public interest, convenience, and necessity"

The standard by which the Commission may grant waivers to the building permit requirement or require building permits for certain stations otherwise exempt.

\section{$\S 325(d)$ - "the public interest"}

One part of the standard by which the Commission may revoke licenses or building permits of foreign stations that can be received in the United States.

§ 332(c)(1)(A)(iii) - "the public interest"

One part of the standard by which the Commission may regulate commercial mobile radio as common carriage. 
$\S 332(\mathrm{c})(1)(\mathrm{C})$ - "the public interest"

Provides a list of factors for the Commission to consider in determining the public interest in $\S 332$ (c)(1)(A)(iii).

$\S 332(\mathrm{c})(2)-$ "the public interest"

The standard by which the Commission may authorize operation of dispatch service on private mobile radio using frequencies allocated for common carrier use.

$\S 332(c)(8)$ - "the public interest"

The standard by which the Commission may impose open access requirements on commercial mobile services.

$\S 335(a)$ - "public interest"

One type of requirement the Commission may impose to regulate direct broadcast satellite providers.

$\S 336(a)(2)$ - "the public interest, convenience, and necessity"

The standard by which the Commission must promulgate regulations for advanced television services.

$\S 336(b)(5)$ - "the public interest, convenience, and necessity"

One part of the standard by which the Commission may impose rules on advanced television services. (This is the catch-all part of the standard.)

$\S 336(d)$ - "obligation to serve the public interest, convenience, and necessity"

Affirmation of the duty of advanced television service providers to serve the public interest generally.

§ 359(e) [47 U.S.C. § 357] - "the public interest"

The standard by which the Commission may regulate free broadcast services. 
§ 362(b) [47 U.S.C. § 360] - "the public interest"

The standard by which the Commission may waive the annual inspection of radio equipment on ships.

$\S 396(a)(1),(2),(6),(9)$ - "the public interest"

A part of the declaration of policy underlying the Corporation for Public Broadcasting.

$\S 396(\mathrm{k})(6)(\mathrm{B})$ - "the public interest"

A part of the duties of the Corporation for Public Broadcasting.

\section{TITLE IV - Procedural and Administrative Provisions}

$\S 412$ - "the public interest"

The standard by which the Commission may choose to keep some public carrier filings confidential.

\section{TITLE VI - Cable Communications}

§ 613(f)(2) [47 U.S.C. § 533] - "public interest"

A category of objectives by which the Commission shall regulate cable television.

§ 614(g)(2) [47 U.S.C. § 534] - "public interest, convenience, and necessity"

The primary standard by which the Commission shall study and regulate program length commercials and broadcast stations designed solely for them.

§ 623(b)(8)(C) [47 U.S.C. § 543] - "the public interest"

The standard by which the Commission may allow temporary increases in basic cable rates for certain stations. 
§ 628(a) [47 U.S.C. § 548] - "public interest, convenience, and necessity"

The standard by which the Commission shall encourage competition in the multichannel video programming market.

$\S 628(c)(1)$ [47 U.S.C. § 548] - "public interest, convenience, and necessity"

A part of the standard by which the Commission shall promulgate regulations to promote competition in multichannel video programming market.

$\S 628(c)(2)(D)$ [47 U.S.C. § 548] - "public interest"

The standard by which the Commission may grant exceptions to certain cable ownership rules.

$\S 628(c)(4)$ [47 U.S.C. $\S 548]$ - "the public interest"

A list of factors by which the Commission shall consider the public interest standard when reviewing exclusive contracts in the video programming market under $\S 628(\mathrm{c})(2)(\mathrm{D})$.

§ 629(e)(3) [47 U.S.C. § 549] - "the public interest"

One part of the standard by which the Commission shall sunset multichannel video programming regulations no longer in the public interest.

§ 652(d)(6)(A)(iii) [47 U.S.C. § 572] - "the public interest"

One part of the standard by which the Commission may waive restrictions on LECs from owning cable service in the same area. necessity"

§ 653(a)(1) [47 U.S.C. § 573] - "public interest, convenience, and

One part of the standard by which the Commission may regulate open access video systems owned by LECs. 


\section{TITLE VII - Miscellaneous Provisions}

§ 705(h) [47 U.S.C. § 605] - "the public interest"

One part of the standard by which the Commission may initiate a rulemaking on universal encryption.

§ 706(b) [47 U.S.C. § 606] - "the public interest"

The standard by which the President may protect interstate or foreign wireline and wireless communications during wartime.

$\S 710(b)(2)(C)(i)$ [47 U.S.C. $\S 610]$ - "public interest"

One part of the authority by which the Commission shall sunset regulations for telephone service to the disabled. 
